\title{
CFD MODEL AS A DIGITAL TWIN OF THE RADIATION STATE OF THE NEW SAFE CONFINEMENT OF THE CHERNOBYL NPP
}

\author{
P.G. Krukovskyi ${ }^{1}$, Ye.V. Diadiushko', V.O. Garin ${ }^{2}$, O.V. Tryfonov ${ }^{2}$, Yu.Yu. Kabanov ${ }^{3}$ \\ ${ }^{1}$ Institute of the engineering thermophysics of NAS of Ukraine, Kyiv, Ukraine \\ E-mail: kruk_2@ukr.net; fax +38(044)456-60-91, tel. +38(044)456-92-81; \\ ${ }^{2}$ National Aerospace University H.E. Zhukovsky "Kharkiv Aviation Institute”, Kharkiv, Ukraine \\ E-mail: garin.vadim@gmail.com; tel.+38(050)454-37-54; \\ ${ }^{3}$ CADFEM Ukraine Ltd., Kyiv, Ukraine \\ E-mail: yuriy.kabanov@cadfem.com.ua; tel. +38(068)442-09-78
}

\begin{abstract}
The necessity of a detailed analysis and prediction of the operating parameters and distribution of radioactive aerosols (RA) in the Shelter Object (SO), the New Safe Confinement (NSC) and the environment of the Chernobyl NPP over the 100-year life of the NSC during the extraction of radioactive waste (RW) from the SO is being justified. For this, a computer CFD (Computational Fluid Dynamic) model has been developed that allows the analysis, prediction and control of the thermogasdynamic, humidity and radiation states of the NSC. The issues of ensuring the adequacy of the model to the various NSC states during long-term operation on the basis of modern technologies of the so-called selflearning "Digital Twin" (Digital Twin) and CFD monitoring of especially important and dangerous objects, especially nuclear, are being considered.
\end{abstract}

\section{INTRODUCTION}

The object of the study is the New Safe Confinement (NSC), built during the span of 5 years and pulled over the Shelter Object (SO) of the Chernobyl NPP in November 2016 (Fig. 1). It is a protective structure, it also includes the equipment for the extraction of radioactive materials (RW) from the destroyed Chernobyl nuclear power unit 4 containing nuclear fuel, the conversion of this power unit into an environmentally friendly system and ensuring the safety of personnel, the public and the environment. The NSC is made of steel structures in the form of an Arch covering the Shelter Object and the technological building, where most life support and control systems are installed [1]. To ensure environmental protection and guarantee long-term corrosion resistance, the structural part of the Arch (see Fig. 1,a) is sheathed inside and outside with two metal shells, - external 2 and internal 3.

The space between the shells of the Arch is called the annular space, and the volume between the inner shell and the structures under the Arch is called the main volume. Ventilation systems are installed in the annular space and the main volume, they should provide the required humidity mode (in order to minimize corrosion of the metal structures of the annular space) and prevent aerosol emissions that may occur in the main volume of the Arch during the dismantling of the OS structures from entering the environment.

The NSC must prevent the leakage of radioactive materials from the destroyed reactor No. 4 into the environment during its dismantling. The dimensions of the NSC Arch are: height about $109 \mathrm{~m}$, length about $164 \mathrm{~m}$, width about $260 \mathrm{~m}$. The air volumes of the annular space, main volume and SO under the NSC are about 1.0 million $\mathrm{m}^{3}$ each, and the total weight of the Arch is about 33 thousand tons.

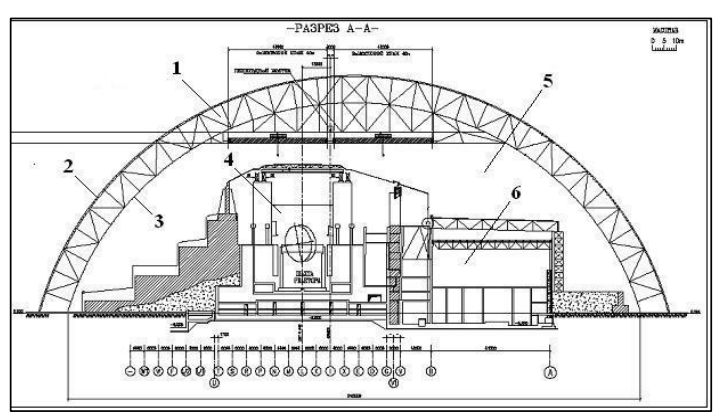

$a$
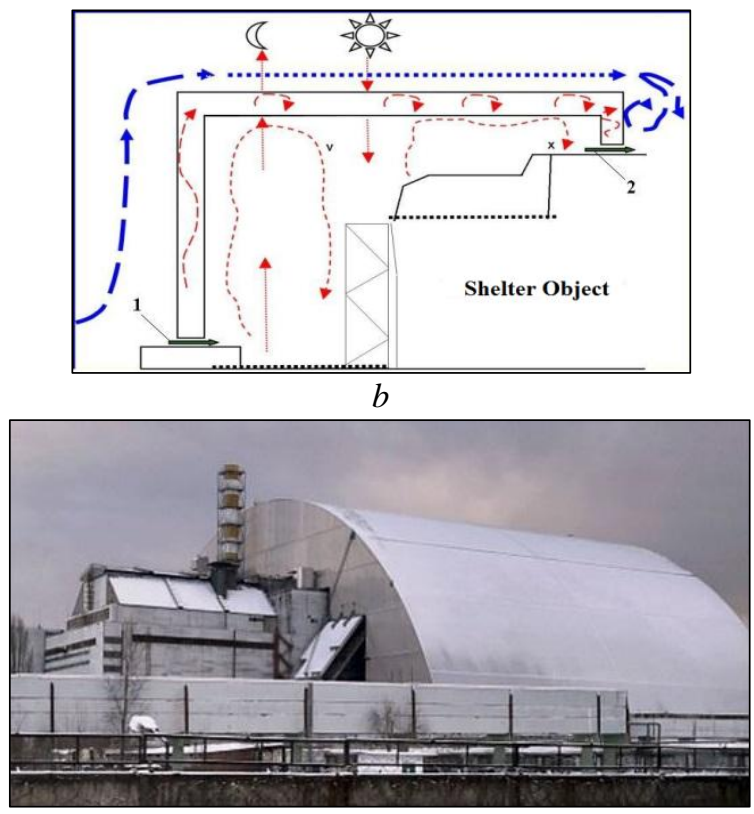

$c$

Fig. 1. Scheme of the Shelter Object and the New Safe Confinement in cross-section (a), longitudinal (b) sections and photo after sliding the NSC onto the

OS (c). In Fig. a: 1- steel structures and annular space of the NSC Arch; 2 -outer shell; 3 -inner shell;

4 - Shelter object and the destroyed reactor;

5 - main volume of the NSC; 6-machine hall 
One of the important engineering systems of the NSC is the ventilation system, which first of all must provide the required relative humidity mode (not more than $40 \%$ ) and the level of excess of air pressure $(50 \ldots 75 \mathrm{~Pa})$ in the annular space of the NSC's Arch, as well as ventilation and maintaining a weak vacuum in main volume under various meteorological conditions. The need to maintain a low level of relative humidity in the annular space of the NSC is dictated by the requirement of minimal corrosion of metal structures located in the annular space to ensure a 100-year resource of the NSC.

An important fact of the influence of climatic conditions (temperature, humidity, as well as the speed and direction of the streamlined outside air) on the thermohumid and radiation state of the NSC should be noted, since the outer and inner shells, as well as the numerous gaps between the NSC and building structures, are not completely airtight there are leaks that will increase over time. The arrows in Fig. 1,b show an example of the movement of air flows when the wind is Western, where 1 is the direction of air inlet into the NSC through the gaps of the Western wall, 2 is the direction of air outflow from the NSC through the gaps of the Eastern wall, and the humid air flows around the NSC can partially pump or suck air from different parts of the annular space depending on the pressure distribution on the outer shell of the NSC due to external air flow around in different directions and wind force.

Since the humidity mode of the air volumes of the NSC's Arch is dependent directly on the temperature and gas-dynamic conditions in these volumes, for a detailed analysis of the operability of the NSC ventilation system, it is necessary to develop an instrument capable of performing such analysis.

A three-dimensional CFD (Computational Fluid Dynamic) computer simulation of the above physical processes in the NSC under various climatic conditions and engineering equipment failures was chosen as a needed instrument.

The aim of the work is a brief description and illustration of the developed model of thermogasdynamic, humidity and radiation states of the NSC and ensuring its adequacy based on the technology of self-learning "digital twins" and CFD monitoring of the NSC's state, which will be in operation for a 100year period during the extraction of radioactive waste from the OS.

\section{CFD-MODEL OF THE SO AND NSC}

In large volumes of the NSC, the distribution of temperature, humidity and RA fields will be significantly uneven and unsteady due to the following complex and interrelated physical processes that the model must take into account:

- radiation-convective interaction of the outer surfaces of the Arch with the environment and the surfaces of the inner shell with the surfaces of the structures of the annular space and the building structures of the SO, as well as the transfer of RA in the main volume of the NSC and out of it;
- external flow around the NSC with ambient air, which leads to the occurrence of complex pressure distributions on the outer shell of the NSC;

- intake of air and moisture from the environment through leaks in the shells and the gaps between the vertical walls of the NSC's Arch and the building structures of the SO;

- heat and mass flows from the annular space to the main volume and sources of internal heat generation in the SO and NSC;

- injection and removal of air to / from the main volume by the inlet and exhaust ventilation systems, which lead to air exchange of the NSC with the environment and the outflow of the RA;

- heat transfer from and to the main volume of the NSC from the ground surface and the foundations on which the NSC is located;

- the heat exchange of massive metal structures of the NSC's Arch, the massive concrete structures of the $\mathrm{SO}$, the soil and foundation on which the NSC is located between each other when considering the influence of climatic conditions during daily, monthly and annual cycles.
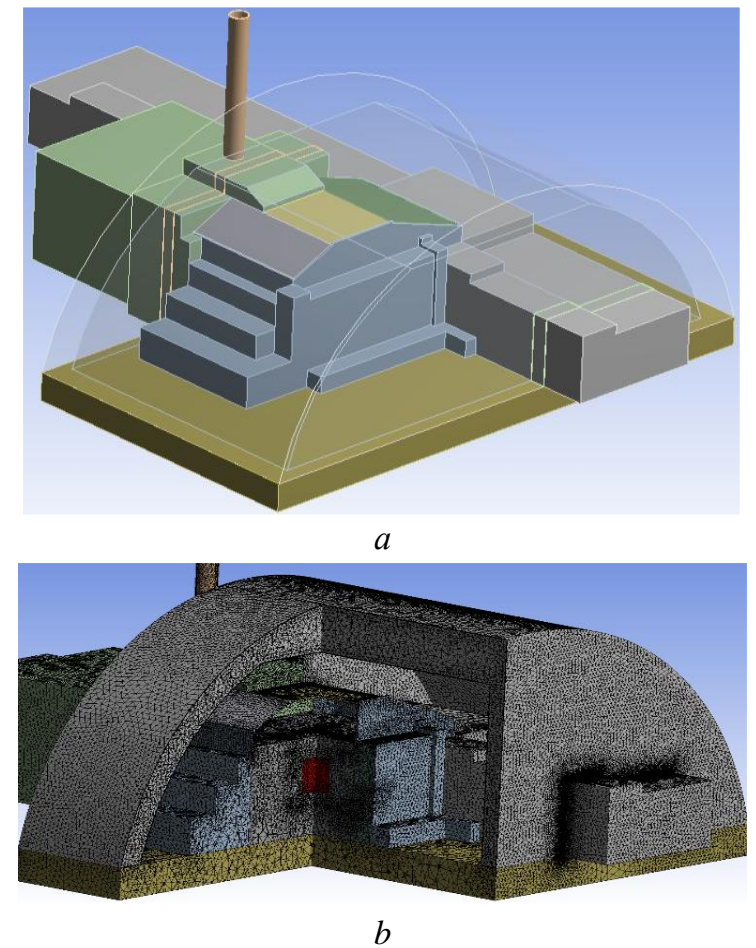

Fig. 2. Parts of the geometric (a) and mesh models of the NSC, SO, soil and foundations $(b)$

A three-dimensional transient CFD-model, which includes all the geometric parts of the NSC's Arch, the objects under it, - the SO, soil and foundations (Fig. 2), and takes into account all the associated physical processes discussed above, was developed in the ANSYS CFD software environment. The computational mesh of the model ranged from 1 to 10 million control volumes, depending on the type of task.

\section{MODELING OF THE NSC`s STATE}

The model of thermogasdynamic and humidity processes in the air volumes of the NSC's Arch, all building structures of the SO, the foundations and soils 
under them was developed and described in [2] and was used for a detailed analysis of the distribution of temperatures and humidity in the annular space and main volume of the NSC and the SO under various climatic conditions in steady-state and transient modes, as well as predicting the heat-moisture state of the SO and the NSC in the event of failure of various parts of ventilation equipment and the distribution of RA inside and outside of the NSC.

Presented below are brief descriptions and illustrations of the solution to the main problems of the NSC's state, necessary for its long-term operation. To simulate each of the problems, a short list of input information is given with a list of parameters that are not well-known, that depend on time and climatic conditions, and therefore should be specified by identifying with measurement data at individual points of the NSC.

\subsection{HEAT AND HUMIDITY STATE OF THE NSC}

Fig. 3 shows an example of a distribution of temperatures and humidity in the annular space and main volume of the NSC and SO in the stationary mode in the summer at an ambient temperature of $30{ }^{\circ} \mathrm{C}$, relative humidity of $100 \%$ and no wind.

The figures show the uneven nature of the distribution of temperatures and humidity in the annular space with lower temperatures and correspondingly high humidity values in the corners of the NSC's Arch. The model allows to consider the non-stationary modes of the volumetric distribution of the temperature field under the NSC in the hourly, weekly, and annual cycles, which is important for the analysis of convective air flows that carry RA from the SO to the main volume of the NSC and outside of it (see also Fig. 4,b, Figs. 5 and $6)$. The main size of the transferred RA is $5 \mu \mathrm{m}$.

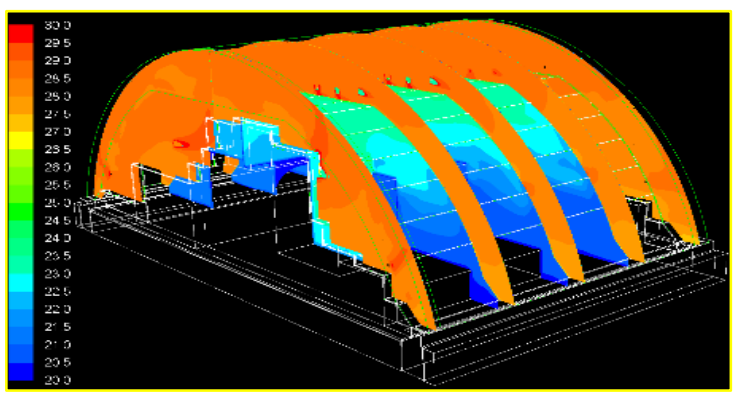

$a$

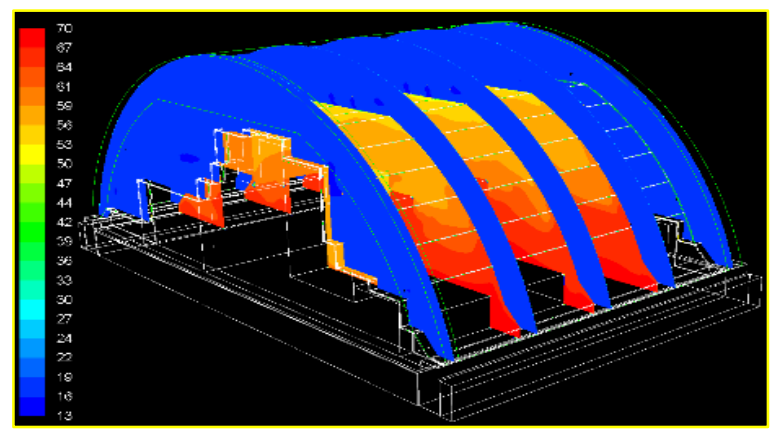

$b$

Fig. 3. Distribution of temperatures ( $a$ ) and humidity (b) in the annular space and main volume of SO and NSC
The input information for performing such analysis is the climatic data, the operation parameters of ventilation units and drying machines, the heat generation in the SO and NSC, as well as the volumes, densities, heat capacities and humidity- and air permeability of individual parts of the SO. The last characteristics should be clarified by identification with the temperature and humidity measurements at individual points of the SO and NSC. An important subtask of this type of tasks is predicting the humidity state of the annular space of the NSC in case of failure of the ventilation equipment.

\subsection{GAS-DYNAMIC STATE OF THE NSC}

As it was mentioned above, the SO contains a large amount of nuclear fuel, solid and liquid radioactive waste (RW) and RA, which must be constantly monitored and taken appropriate measures of to reduce the impact on personnel and the environment of the NSC. Although the NSC to some extent isolates the SO, reducing the amount of RA emissions into the environment, but the release of RA from the SO continues to the internal airspace (the main volume) of the NSC itself, where the NSC and SO personnel work. The main driving force of the RA exit from the SO, as noted above, is the non-stationary thermogasdynamic processes inside the SO and the NSC, namely, thermal convection and air movement due to temperature differences between the separate zones and the NSC (see Fig. 4,a), in particular areas where there are fuelcontaining masses (FCM). Such temperature differences inside the SO depend on the time of year, the activity of the personnel in the SO, the thermal state of the NSC and others.

On the other hand, the RA from the NSC partially enters the environment since the NSC structure and the gaps between the vertical walls of the NSC and the concrete building structures under them are not airtight. The level of RA output from the NSC directly depends on the direction and speed of the wind; therefore, the external flow around the NSC is also modeled using the CFD model shown in Fig. 4,b. The largest air outflow with the RA takes place through the gaps between the vertical walls of the NSC and the building concrete structures, marked with yellow lines in Fig. 4,b.

These leakages of the NSC can be characterized by the total size of the areas of air leaks between the parts of the NSC and the NSC with the environment. Thus, according to the design at the end of the service (after 100 years), leakages through the outer shell of the NSC (see Fig. 1,b, Table 1) should increase by about 5 times compared with the beginning of the service, and the real value determined by special tests using the developed in 2018-2020 model, they have already shown to be 6.5 times bigger reaching $1.7 \mathrm{~m}^{2}$ (Table 1). For the Western and Eastern gaps (see Fig. 1,b) they are approximately 5 and 2 times bigger than the designed gaps.

It is the Western and Eastern gaps that let air flow from the NSC into the environment along with radioactive aerosols (RA). The flow rates of this air together with the RA substantially depend on the direction and speed of the wind that flows around the NSC from the outside. 


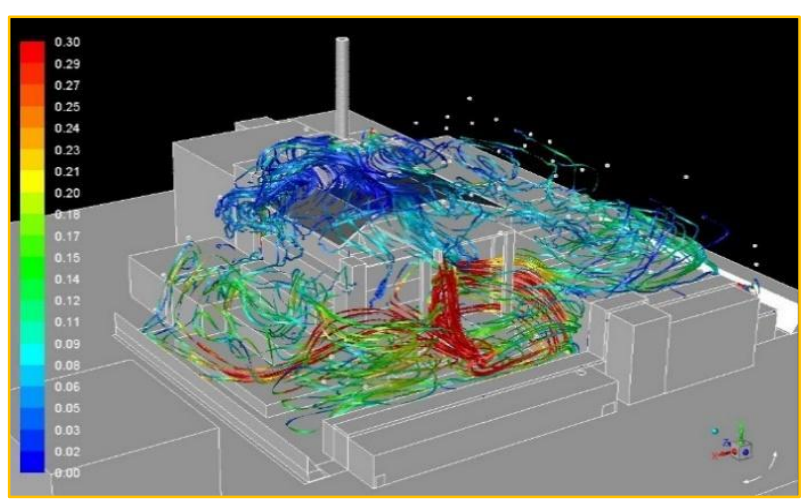

$a$

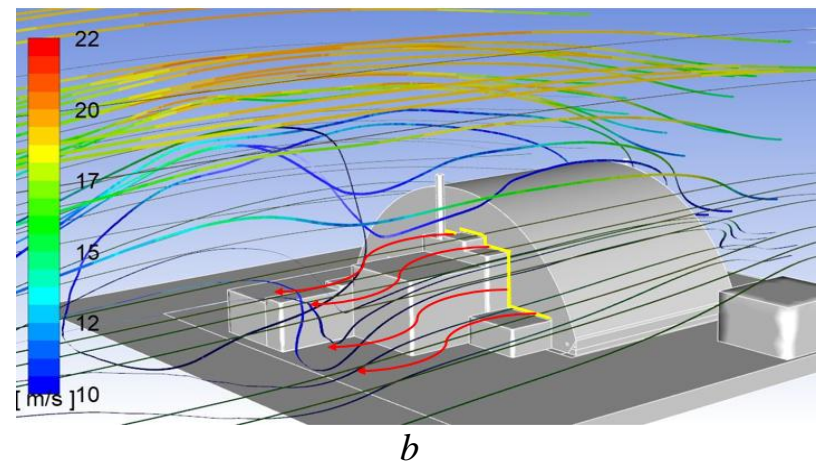

Fig. 4. Airflow lines inside the NSC over the SO (a) (the $N S C$ 's Arch is not visible, example of the winter season) and outside the NSC $(b)$

Dimensions of designed and actual areas of air leaks between the NSC and the environment

\begin{tabular}{|l|c|c|c|}
\hline \multirow{2}{*}{$\begin{array}{c}\text { Leak } \\
\text { points }\end{array}$} & \multicolumn{2}{|c|}{ Design estimations, $\mathrm{m}^{2}$} & $\begin{array}{c}2019-2020 \\
\text { model }\end{array}$ \\
\cline { 2 - 4 } & $\begin{array}{c}\text { Start of } \\
\text { operation }\end{array}$ & $\begin{array}{c}\text { End of } \\
\text { operation }\end{array}$ & $\begin{array}{c}\text { Start of } \\
\text { operation }\end{array}$ \\
\hline Outer shell & 0.26 & 1.2 & 1.7 \\
\hline Inner shell & 0.24 & 1.1 & 6.05 \\
\hline $\begin{array}{l}\text { Western } \\
\text { gap }\end{array}$ & 0.6 & 0.6 & 3.1 \\
\hline $\begin{array}{l}\text { Eastern } \\
\text { gap }\end{array}$ & 1.8 & 1.8 & 3.9 \\
\hline
\end{tabular}

The air outflow with the RA through the gaps between the vertical walls of the NSC and the concrete building structures occurs due to the wind flowing around the NSC and the formation of an uneven distribution of pressure on the outer shell, walls and gaps of the NSC, which values are positive in the Western wall and gap and negative in the Eastern wall and gap values when the wind is Western (and vice versa), and can reach hundreds of Pascals. Preliminary calculations showed that the air flow through these gaps with a negative pressure value can reach $30 \%$ of the main volume's exhaust ventilation flow rate that goes through filters. Based on this, the possibility of analyzing and predicting the distribution of radioactive aerosols (RA) not only inside but also outside the NSC into the environment when dismantling the existing $\mathrm{SO}$ and extracting radioactive materials is an urgent and important task, the solution of which allows to quantify (monitor) RA emissions into the environment depending on their concentration level inside the NSC, as well as the direction and speed of the wind.

It should be noted that this gas-dynamic part of the model makes it possible to determine such control modes of ventilation units which give minimal air outflow from the NSC.

The input information for performing such an analysis is also the climatic data and operation parameters of ventilation units, and the values of the areas of air leakage between the NSC and the environment (Table) should be periodically checked and refined by the model by identifying the pressure and its differences with the environment from the measurement data in the annular space and main volume of the NSC.

\subsection{RADIATION STATE OF THE NSC}

The model allows to perform the analysis and prediction of the distribution of RA inside and outside the NSC during the extraction of FCM from the SO, which is the most important during the operation of the NSC. Since such work has not yet been carried out, we will show the possibility of the model in the following typical scenario with a more detailed description. To estimate the radiation state of the internal space of the NSC with significant emissions of RA, a transient calculation was carried out using a model of the state of the SO and the NSC during the works on the extraction and loading of RW in the central hall of the SO (Fig. 5,a). The calculations are based on the initial data and the results obtained by the authors of [3], in which they carry out a similar estimation based on the analytical solution of the differential equation for the balance of the amount of RA in the main volume (MV) of the NSC. A significant difference between the calculations using the three-dimensional CFD model is the ability to obtain a distribution of local RA concentrations, while the authors' approach [3] allows to calculate only the average concentrations in the entire main volume of the NSC.

Modeling was carried out under the conditions of the dismantled roof of the SO and the operation of the inlet and exhaust ventilation of the NSC, which corresponds to the operating conditions of the NSC. The emission of RA occurs during the loading of RW into the container. Work is carried out in 2 shifts per day. For one shift, $2 \mathrm{~h}$ is spent on loading of RW into a container, accompanied by the release of RA, after which it is transported. Then the second container with RW is loaded also within $2 \mathrm{~h}$, after which the work shift ends. Every day, this cycle repeats. 


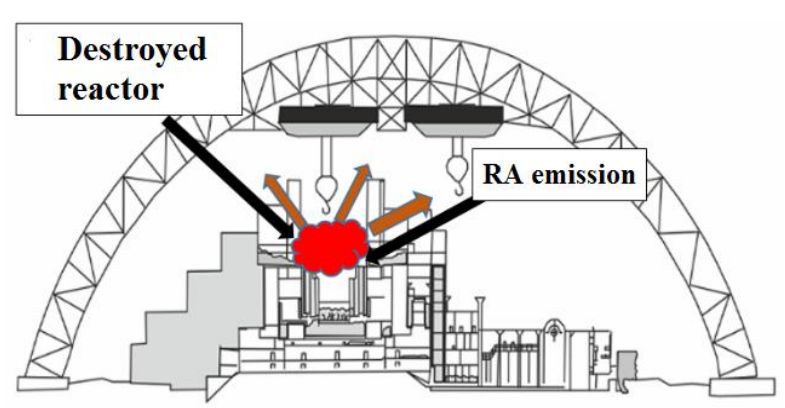

a

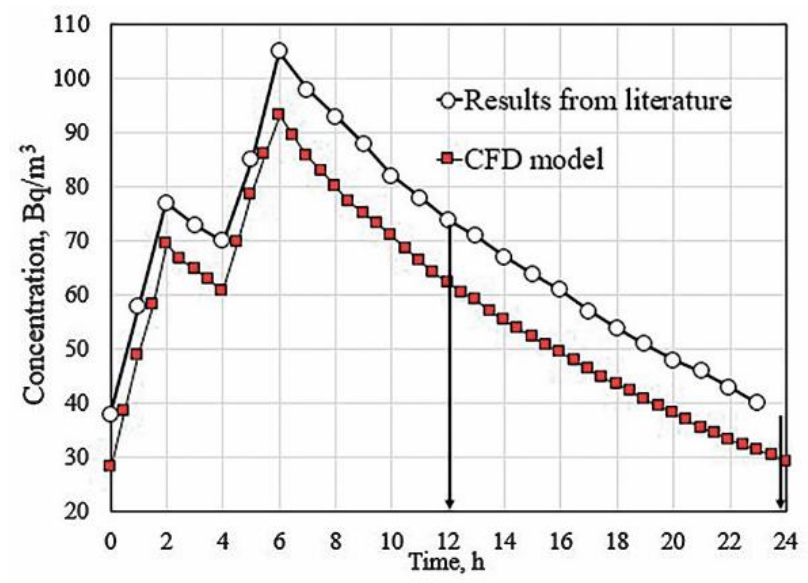

$b$

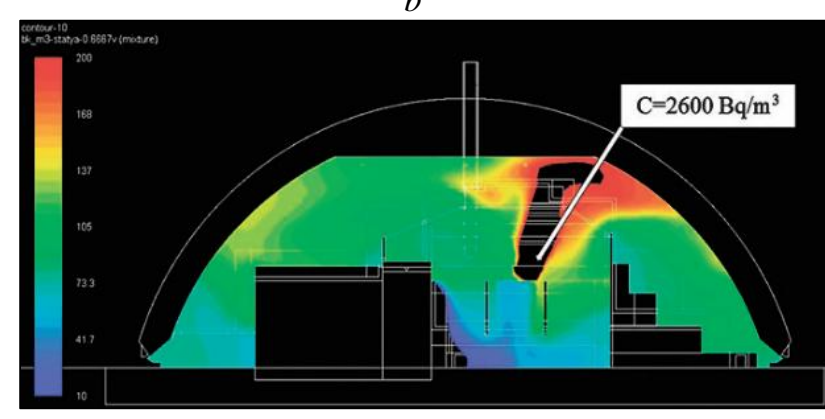

$c$

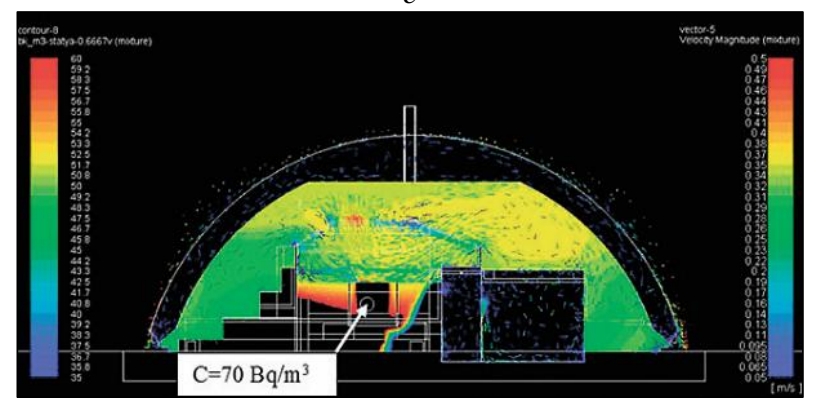

$d$

Fig. 5. The scenario of RA outflow from the central hall of the $S O(a)$, the dependence of the average volume concentration of RA on time (b), obtained in [3] and the $C F D$ model, and the volume distribution of $R A$ in the main volume of NSC after $6(c)$ and $12 h(d)$ from the start of work

In the CFD models of the NSC and SO, emission occurs locally in the obstruction zone of the reactor hall of the SO (see Fig. 5,a,c,d). The released dust does not evenly spread throughout the internal volume of the NSC and, ultimately, is removed by exhaust ventilation from the OO. The emission rate of RA in the models was taken to be $0.316 \mathrm{~kg} / \mathrm{h}$, estimated on the basis of such data: container volume $-3 \mathrm{~m}^{3}$, specific RW emission $K=0.169 \mathrm{~kg} / \mathrm{t}, \quad$ specific RA activity $A=1 \cdot 10^{8} \mathrm{~Bq} / \mathrm{kg}$, emission value $E=3.16 \cdot 10^{7} \mathrm{~Bq} / \mathrm{h}$. The air exchange of the NSC`s MV, and, consequently, the speed of the RA withdrawing during the operation of the NSC is determined by the exhaust ventilation flow rate and the MV value. To get closer to the initial data [3] in the CFD model, the exhaust ventilation flow rate was used, which provided an air exchange rate of 1.4 volumes/day.

An essential assumption of work [3] was not to take into account the spatial location of the RA source, the ventilation system pipes and the general geometric configuration of the NSC`s MV, and, therefore, the inhomogeneous distribution of the RA concentration over the space, as well as dust settling on horizontal surfaces under the NSC, were not taken into account. In CFD models, such assumptions were absent.

The obtained time dependence of the RA concentration in the NSC's MV obtained by both models is shown in (see Fig. 5,b).

Fig. 5,c,d also show the distribution of concentrations at times of maximum concentration $(6 \mathrm{~h}$ from the start of the shift), as well as $12 \mathrm{~h}$ after the start of the shift. It can be seen from the comparison results that the average volume concentration of RA obtained as a result of CFD modeling are close to the results of [3], however, the results of CFD modeling are lower due to the neglect of dust precipitation in calculations [3].

As noted above, the great advantage of CFD modeling is the ability to quantify the distribution of RA concentration levels in the airspace of the NSC. So for this example, it can be seen that local concentrations of RA near the place of loading of RW into containers at certain points in time can reach $\sim 2.6 \mathrm{kBq} / \mathrm{m}^{3}$, which significantly exceeds the permissible value of $200 \mathrm{~Bq} / \mathrm{m}^{3}$ for personnel, and even less at the entrance to the lock chamber for containers transporting.

Analysis of RA movement in the main volume of the NSC and possible emissions into the environment through leaks between the vertical walls of the NSC and the SO`s buildings, in addition to the removal of RW, is also important during the dismantling of unstable structures of the $\mathrm{SO}$ and therefore one of the main tasks of the NSC is to constantly analyze the level of RA in the main volume of the NSC and outside of it, its impact on personnel who will work there during the dismantling of blockages and removal of FCM and FCW from the SO during the entire life of the NSC. For this, the model allows us to represent the distribution of RA concentrations of different levels simultaneously in the form of isosurfaces both inside and outside the NSC (Fig. 6).

Thus, it can be stated that the radiation state of the NSC is best described by the CFD model described above, which makes it possible to obtain the distribution of RA values in the entire volume of the NSC as part of the NSC's state monitoring system, which also makes it possible to predict reaching of critical RA values and take the necessary measures for personnel protection. 


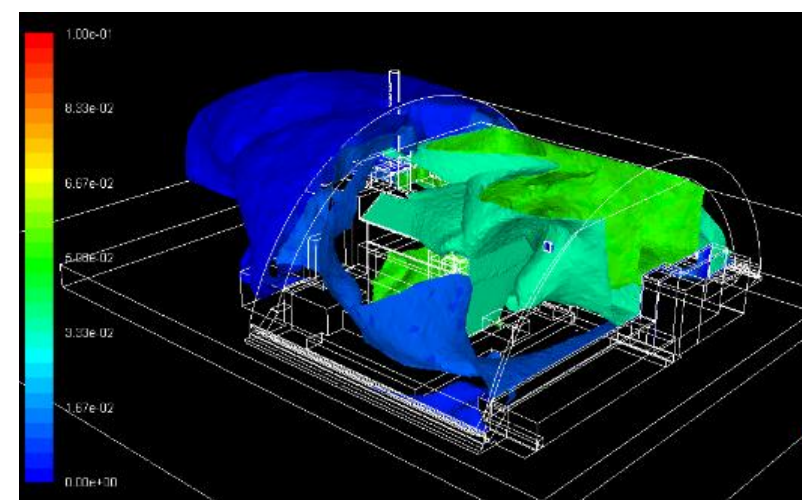

Fig. 6. Distribution of RA concentration $\left(\mathrm{Bq} / \mathrm{m}^{3}\right)$ inside and outside the NSC in the form of isosurfaces of different levels

The input information for performing such an analysis is the measured values of RA concentrations at individual points in the central hall of the $\mathrm{SO}$ and the main volume of the NSC, with which the model should identify the intensity of the RA source, as well as reconstruct and predict the volume field of the RA inside and outside the NSC.

\section{CFD-MODEL-DIGITAL TWIN OF THE NSC}

For the effective application of the considered model of the NSC's state, it is necessary to ensure its adequacy to the real state of the NSC. When considering individual subtasks to be solved with the help of the model, the parameters of the model were indicated (total 10-15), which must be identified by the received data of the NSC's state. Such state measurements are taken at various points of the NSC with different frequencies during its life. According to this data, the model should constantly adapt (self-learn) in automatic mode, what is the most important and difficult to implement. For such learning, the model must be in constant or periodic interactive communication with the serviced object, take into account changes in it, and be prepared to predict and, if necessary, manage its state.

To meet such requirements, the concept of so-called "digital twins" has now appeared in the methodology for modeling various objects (and processes, including technological) with related software. We will consider the existing definitions, methodology, software implementation of the "digital twins" concept.

In [4], Digital Twin is defined as a software analogue of a physical device that simulates internal processes, technical characteristics, and behavior of a real object under the influence of interference and the environment. In fact, this is a set of mathematical models and submodels [5] that describe the state of an object and all its elements. In the general case, a digital twin includes: a geometric model of an object, a set of calculated data of parts, assemblies, and the object as a whole, mathematical models that describe all physical processes occurring in an object, information about technological processes of manufacturing and assembly of individual elements, some data on object tests, for example, readings of sensors with which calculated data can be confirmed, a product life cycle management system that links all of the above objects into a single structure.

A positive feature of the digital twin is its interaction with sensors of a real object. The information that comes from real sensors is compared with the calculations of a digital twin, which allows refinement of the model parameters. This is useful both at the stage of creating a digital twin and at the stage of its operation, since the parameters of a real object can change over time and they need to be promptly updated in the developed model of a real object to ensure its adequacy.

The relevant approach to connecting a digital twin with a real object is cloud services, which, in general, makes the digital twin an important participant in the socalled Industrial Internet of Things (IIoT).

Software is also being developed for creating digital twins of various objects, which also include means of validation and interactive integration with a real object.

Some examples of such programs are given below.

1. ANSYS Twin Builder software [6] allows you to create, verify and deploy digital twins based on simulation within a single workflow with IIoT data, which allows you to switch to reduced-order models (ROM) from 3D models, perform multivariate calculations to accelerate preliminary analysis and optimization, then go back to the 3D model with the import of the results of reduced-order models for more detailed tuning and optimization of parameters, as well as the use of a number of popular IIoT platforms for the integration of digital counterparts with serviced objects.

2. Altair HyperWorks software [7], created to simulate an object as a digital twin using a cloud platform with IIoT Carriots technology for managing a digital twin and linking data with the concept, development and verification of the design stage of the product-object and transmitting the data back to the user to make important decisions, such as equipment maintenance planning, which allows you to combine these two software products.

3. ThingWorx 8 software [8] created to simulate and optimize a digital twin with an emphasis on optimizing the life cycle (resource) and communication with a real object (industrial IoT data), as well as the ability to integrate with ANSYS Simplorer (Twin Builder) for simulation with reduced order models (ROMs) derived from 3D models that are also compatible with ThingWorx 8.

Summarizing the above about digital twins and its capabilities and comparing them with the developed and described model of the state of the NSC, we can say that this CFD model is essentially created as a digital twin of the NSC of the ChNPP. There are several reasons for saying so. First of all, the NSC is an important technogenic object, which should ensure the radiation safety of the Chernobyl NPP and the environment. Secondly, the service life of the NSC should be at least 100 years - the time required to turn the destroyed 4th power unit into an environmentally safe system. It seems to us that for such a long-term service of the NSC, the CFD-model-digital twin of its state should be included in the NSC's monitoring system, the scheme of which is presented below. 


\section{MONITORING OF THE NSC`s STATE}

The following requirements can be formulated for such a system for monitoring the state of the NSC:

1. The existence of a CFD model of the object, which describes the state of the object in detail.

2. The interaction of the CFD model with the measured parameters of the object.

3. The existence of a procedure for identifying model characteristics according to measurements at individual points of the NSC.

4. The use of a CFD model of an object for predicting the state of an object, for example, predicting possible emergency situations.
5. The work of the CFD-model in automatic mode in "real" time.

Fig. 7 shows the proposed scheme for the interaction between the components of the radiation situation monitoring system of the NSC and SO with each other as well as with the NSC. Such monitoring is called CFD-monitoring by the authors, since it is based on the use of CFD models.

As can be seen from the figure, monitoring materially consists of 2 parts - software and hardware.

For its functioning, in addition to these two parts, only data exchange (via the Internet) between the NSC and the monitoring system is required.

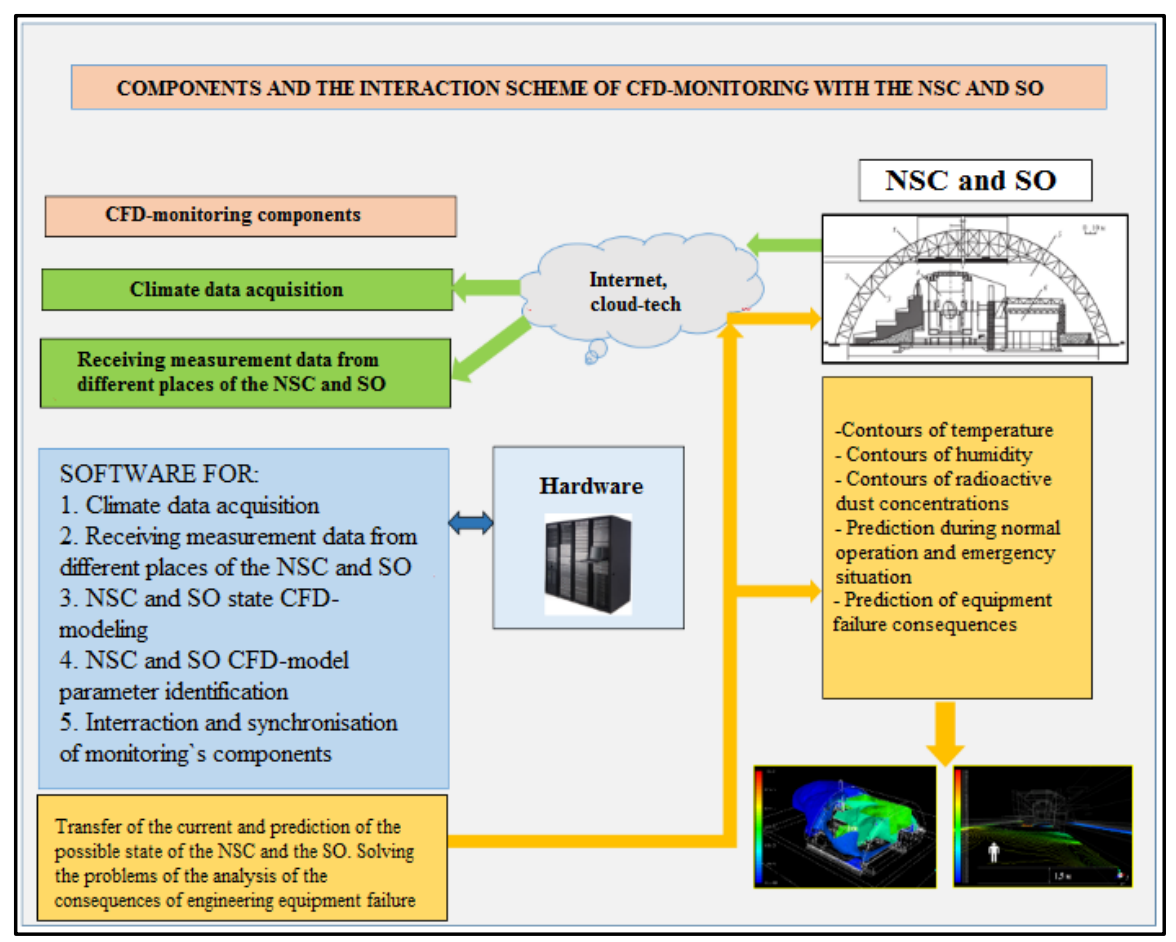

Fig. 7. Scheme of interaction between the components of the radiation state of the NSC and SO monitoring system with each other and via the Internet

Thereby, the developed model can be included in the system of constantly operating monitoring of the NSC and SO as the so-called "digital twin of the NSC", which allows analyzing and predicting of its state and clarifying operational parameters during various standard and emergency situations throughout the life of the NSC.

The use of the NSC ChNPP's digital twin will significantly facilitate the successful implementation of the project to transform the Chernobyl Shelter Object into an environmentally safe system [9].

\section{CONCLUSIONS}

A computer CFD model of the thermogasdynamic, humidity, and radiation state of the NSC has been developed, which allows detailed analysis and prediction of the operational parameters and radiation state of the NSC and the environment near the site of the Chernobyl NPP over a 100-year period of operation of the NSC during RW extraction from the SO.
To ensure the adequacy of the model to various NSC states during long-term operation, it should possess the properties of the so-called "digital twins" and should be the basis of the developed CFD monitoring of the NSC's state, which in turn should be included in the existing integrated NSC and OS control system [10]

The novelty of the work is to set out the possibilities and analyze the requirements for the developed CFD model of the radiation state of the NSC as a digital twin to ensure its operability as part of the NFC CFD monitoring.

The work was carried out with financial and informational support from the VINCI Construction Grands Projets / Bouygues Travaux Publics NOVARKA consortium, the Chernobyl NPP, the National Academy of Sciences of Ukraine and the NATO science program "Science for Peace and Security". 


\section{REFERENCES}

1. В.К. Толстоногов, А.Д. Гора, В.Н. Кулишенко, R. Loos, M. Durst, K.А. Фащевский. SIP-P-PM21-330-TOR-001-01, ред. 1 от 05.10.2001. Техническое задание на разработку Концептуального проекта (ТЭО) безопасности конфайнмента / ДСП «ЧАЭС». 2001, 290 с.

2. П.Г. Круковский, М.А. Метель, Д.И. Скляренко и др. Новый безопасный конфайнмент Чернобыльской АЭС (расчетно-экспериментальный анализ при проектировании и эксплуатации): / Под ред. П.Г. Круковского, В.А. Краснова и В.П. Сулимова. Киев: ООО «Франко Пак», 2019, $300 \mathrm{c}$.

3. В.Г. Батій, А.О. Сізов, Д.В. Федорченко, А.О. Холодюк. Динаміка зміни концентрації радіоактивних аерозолів під час вилучення паливовміщуючих матеріалів з об'єкта «Укриття» // Ядерна та радіаційна безпека. 2015, в. 4, с. 41-44. Режим доступу: http://nbuv.gov.ua/UJRN/ ydpb_2015_4_10.

4. Цифровизация / Цифровой двойник CADFEM CIS / https://www.cadfem-cis.ru URL: https://www.cadfem-cis.ru/service/digital-twin/ (дата обращения 04.08.2020).

5. Цифровой двойник: зачем создавать в виртуальной среде симуляторы деталей, двигателей и целых цехов / https://cheremuha.com URL: https://cheremuha.com/2018/04/13/digital-twin.html (дата обращения: 04.08.2020).

6. First of Its Kind Solution for Digital Twins in ANSYS 19.1 / https://www.ansys.com URL: https://www.ansys.com/blog/digital-twins-solutionansys-19-1 (дата обращения: 04.08.2020).

7. Carriots IoT Platform Offers Gateway to the Digital Twin / https://www.engineering.com URL: https://www.

engineering.com/IOT/ArticleID/15680/Carriots-IoTPlatform-Offers-Gateway-to-the-Digital-Twin.aspx?e_ src=relart (дата обращения: 04.08.2020).

8. ThingWorx 8 Releases Manufacturing Apps and

Simulation for the Digital Twin / https://www.engineering.com . URL: https://www. engi-neering.com/IOT/ArticleID/14963/ ThingWorx-8Releases-Manufacturing-Apps-and-Simulation-for-the-

Digital-Twin.aspx?e_src=relart (дата обращения: 04.08.2020).

9. Новый Безопасный Конфайнмент / https://chnpp.gov.ua

URL:https://chnpp.gov.ua/nbk/index.html

(дата обращения: 04.08.2020).

10.Новый безопастный конфаймент. Интегрированная система управления. Проект ИСУ. Пояснительная записка: Отчет / СП HOBAPKA. - SIP-N-AC-22-B2172-TEN-200-01.

\title{
CFD-МОДЕЛЬ КАК ЦИФРОВОЙ ДВОЙНИК РАДИАЦИОННОГО СОСТОЯНИЯ НОВОГО БЕЗОПАСНОГО КОНФАЙНМЕНТА ЧЕРНОБЫЛЬСКОЙ АЭС
}

\author{
П.Г. Круковский, Е.В. Дядюшко, В.О. Гарин, О.В. Трифонов, Ю.Ю. Кабанов
}

Обосновывается необходимость детального анализа и прогнозирования рабочих параметров и распределения радиоактивных аэрозолей (РА) в Объекте «Укрытие» (ОУ), новом безопасном конфайнменте (НБК) и окружающей среде Чернобыльской АЭС на протяжении 100-летней эксплуатации НБК при извлечении радиоактивных отходов (PAO) из ОУ. Для этого разработана компьютерная CFD (Computational Fluid Dynamic) модель, позволяющая проведение анализа, прогнозирования и управления термогазодинамического, влажностного и радиационного состояний НБК. Рассматриваются вопросы обеспечения адекватности модели различным состояниям НБК при длительной эксплуатации на основе современной технологии так называемых самообучающихся цифровых двойников (Digital Twin) и CFD-мониторинга особо важных и опасных объектов, особенно ядерных.

\section{СFD-МОДЕЛЬ ЯК ЦИФРОВИЙ ДВІЙНИК РАДІАЦІЙНОГО СТАНУ НОВОГО БЕЗПЕЧНОГО КОНФАЙНМЕНТА ЧОРНОБИЛЬСЬКОЇ АЕС}

\section{П.Г. Круковський, С.В. Дядюшко, В.О. Гарін, О.В. Трифонов, Ю.Ю. Кабанов}

Обгрунтовується необхідність детального аналізу та прогнозування робочих параметрів і розподілу радіоактивних аерозолів (РА) в Об'єкті «Укриття» (ОУ), новому безпечному конфайнменті (НБК) i навколишньому середовищі Чорнобильської АЕС протягом 100-річної експлуатації НБК при добуванні радіоактивних відходів (РАВ) з ОУ. Для цього розроблена комп'ютерна CFD (Computational Fluid Dynamic) модель, що дозволяє проведення аналізу, прогнозування та управління термогазодинамічного, вологісного $\mathrm{i}$ радіаційного станів НБК. Розглядаються питання забезпечення адекватності моделі різним станам НБК при тривалій експлуатації на основі сучасної технології так званих самонавчающихся цифрових двійників (Digital Twin) i CFD-моніторингу особливо важливих і небезпечних об'єктів, особливо ядерних. 